\title{
Improving Students Skills in Writing Letters of Commerce by Developing Correspondence Module-based POE (Predict-Observe-Explain)
}

\author{
Novita Kumalasari \\ Madziatul Churiyah \\ Program Studi Pendidikan Administrasi Perkantoran Universitas Negeri Malang \\ Erna Sukmawati \\ SMK N 1 Malang \\ E-mail: madziatul.churiyah.fe@um.ac.id
}

\begin{abstract}
The purpose of this study is: generate a module-based POE (Predict-Observe-Explain) correspondence on the subject matter of making procedures commercial letters, know the feasibility of module, and knowing the difference skill writing letters that do not use the modul correspondence with the letter writing skills using a module correspondence. This type of research and development and modul after being validated matter expert, expert modules, and 12 students with result very valid/usable. The skills of letter writing in students with $t$-test calculations in SPSS, it is known that a significant difference between the average student learning outcomes experimental class and control class.
\end{abstract}

Keywords: Module, POE, Correspondence, Writing a Letter

Education is a very important aspect to be noticed in order to produce good quality human resources, when the education system in a country can be implemented properly, it will produce a good quality human resources. The definition of education in particular have been regulated in UU Nomor 20 tahun 2003 States that "pendidikan merupakan suatu usaha sadar dan terencana yang dilakukan oleh pendidik melalui bimbingan, pengajaran, dan latihan untuk mewujudkan suasana belajar dan proses pembelajaran agar peserta didik aktif yang mengarah pada tercapainya pribadi yang dewasa". When observing the direction of the educational development in the era of the tranformation of science and technology and the globalization of life, then it appears that the learning process in the classroom must be able to lead an effort to build a competitive learning climate, independent learning and capable of learning encourages students to internalize and transform new knowledge. The learning strategy patterns by the experts often called the pattern learning with contructivistic approach.

When observing the direction of the education development in the era of tranformasion of science and technology as well as the globalization, it appears that the learning process in the classroom must be able to lead an effort to build 
a competitive learning climate, the independent learning and capable of learning encourages students to internalize and transform new knowledge. The learning strategy patterns by the experts are often called the learning pattern with contructivitic approach (Liew \& Treagust, 2004; Kibirig et al., 2014; Tlala, 2011; Ayvaci, 2013; White \& Gustone (in Karamustafaoglu, 2015); Widyaningrum, et al. 2013; Warsono \& Hariyanto, 2016).

Therefore the use of the contructivitic approach by each teacher in the learning process in the classroom is a must so that studentss can develop their potential. In fulfilling the purpose of constructivist learning, there needs to be a change of the learning that is teacher centered into the learning that is student centered. Student centered learning is learning that requires learners to explore, process, and discover their own knowledge. The role of teacher in learning are student centered is as a facilitator, that teachers should be able to provide facilities that allow ease learning activities of learners and creating a fun learning environment. In adintion, teachers should be able to initiate the appropriate learning materials and can achieve learning objectives.

Curriculum changes from KTSP curriculum (Kurikulum Tingkat Satuan Pendidikan) into the 2013curriculum, got a different response from the community. Basically, the reason for the change of the curriculum is one of the targets that must be resolved in accordance with the Rencana Pembangunan Jangka Menengah Nasional (RP JMN) 2010-2014 in the education sector. In 2013 the lesson that the curriculum is more centred on learners and are demanding learners to be more active in the process of teaching and learning. Changes to the curriculum is also done to answer the challenge of the times are constantly changing so that the learners are able to compete in the future.

Implementation of 2013 curriculum will run with maximum, if supported by the facilities and infrastructure in the learning process in order to be fulfilled satisfactory student learning outcomes. One of the facilities and infrastructure that support the learning process of students namely textbooks or books package. The textbook is the book that made the handle students as a source of learning and media (instructional).

Based on the above issues, the availability of learning materials can be used as references or solutions to overcome these problems. The development of learning materials can be done in the form of a variety of text books in the Permeninkbud No. 2 tahun 2008 about the book, such as modules, LKS, diktat, and other books. Daryanto (2013:9) States "Modul merupakan salah satu bentuk bahan ajar yang dikemas secara utuh dan sistematis, didalamnya memuat perangkat pengalaman belajar yang terencana dan indesain untuk membantu peserta didik menguasai tujuan belajar yang spesifik". In this research, researchers developed learning materials in the form of modules.

In adintion to learning materials, appropriate learning methods are also necessary in the learning process. Methods and new approaches developed to support the implementation of many of the learning-oriented contrustivist. One that is developed is POE (Predict-Observe-Explain). Liew \& Treagust (2004) learning model that POE can be used by teachers to provide a deep understanding on the activity of learning and strategies desig that start of learning from the perspective of learners not teachers or experts of science. 
POE learning model is a learning model based on the theory of contructivism (Liew \& Treagust, 2004; Kibirige et al., 2014; Tlala, 2011; Ayvaci, 2013; White \& Gustone (in Karamustafaoglu, 2015); Widyaningrum, et al. 2013; Warsono \& Hariyanto, 2016). Widyaningrum, et al (2013) stated that " Model ini merupakan salah satu model berorientasi konstruktivisme yang menekankan pada cara siswa membangun atau menemukan pengetahuan sendiri". Contructivist theory is theory through scientific approaches. This is because, the scientific approach has some step in learning that demand students to find answers themselves. The teacher's role is as a facilitator (Tlala, 2011).

Liew \& Treagust (2004) stated that the learning model with POE can be used by teachers to provide a deep understanding on the learning activity and strategies that start learning from the viewpoint of the students rather than teachers or experts of science. White and Gunstone (Keeratichamroen, 2007) reveals that POE is a learning model steps that are efficient to create discussion students in predicting a phenomenon, doing observation through demonstrations or experiments, and finally describes the results of the demonstration as well as their previous forecasts. Based on the description above, the researcher tried to develop the Correspondence learning module by using POE model (Predict-Observe-Explain). Correspondence Module-based POE (Predict-Observe-Explain) this is a module that can be used independently by students and will make it easier for students to learn gradually. The purpose of this research is 1) generates a corresponinng module-based POE (Predict, Observe, Explain) the subject matter of making procedures commercial mailings to improve letter writing skills; 2) know the feasibility of a Correspondence module has been developed through the results of validation experts and students as a user; 3 ) knowing the difference skill writing letters that do not use materials in the form of module Correspondence-based POE with the letter writing skills using learning materials in the form of module Correspondencebased POE.

\section{METHOD}

This research uses the methods of Research and Development (R \& D) that refers to the model of the Borg and Gall (in Setyosari 2013). Measures based on research and development, developed by Borg and Gall (in Setyosari 2013), then do some simplification steps into 8 research and development to field test steps. Step into the nine to ten not done because by the eighth step has been able to demonstrate the feasibility criteria of the module and knowing the difference skill writing students. 


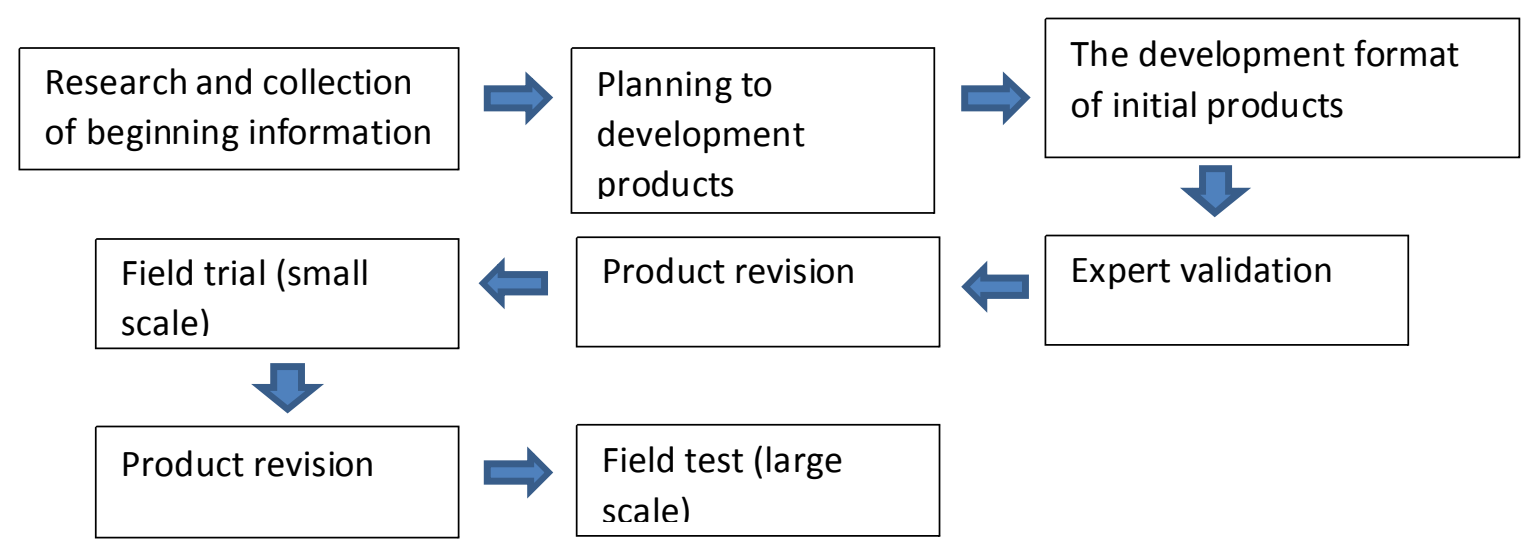

Figure 1. Procedure Development Module (Modification Of Model Results)

This research was conducted in the SMK Negeri 1 Malang class X Keahlian Administrasi Perkantoran program. The subject field trials (small scale) of 12 students and field test (large scale) which is divided into a experimental class of 36 students and control of 36 students. While the validation of a product involves 4 validator, 2 material experts are from the subject teachers who master the material correspondence in SMK Negeri 1 Malang, and 2 expert modules who are experts in the field of learning media with S2-Educational Technology qualifications, Faculty of Education Sciences at Universitas Negeri Malang.

Needs analysis data are analyzed qualitatively and quantitatively. Data analysis the assessment of experts regarding the development of Correspondence module-based POE in the form of score converted to qualitative data (data intervals) on a scale of five. Small-scale test data using descriptive analysis technique percentage. Meanwhile, to analyze differences in letterwriting skills to students using POE-based modules and those not using POEbased modules are done with post-test.

\section{RESULTS \& DISCUSSION}

\section{Results}

Development of modules conducted by researchers that is produce in the form of printed materials, namely Correspondence Module-based POE (PredictObserve-Explain) the subject matter of making procedures commercial letter. The module is developed there are four learning activities based on their respective subject matter, namely (1) learning activities 1 consisted of the material sense of the letter, the definition of commercial letters, letters of introduction; (2 learning activities 2 consist of material letter of request and letter of offer; (3) learning activities 3 consists of the material of mail order, the notice of delivery, payment and delivery of letter mail Bill; (4) learning activities 4 consist of complaint letter material and letter of complaint settlement.

This module was developed to support the teaching and learning in the classroom and improves the results of learning psychomotor (skills writing letters) on Class X Progam Administrasi Perkantoran in SMK Negeri 1 Malang 
based2013 curicculum. The development of Correspondence Module using the learning model of POE (Predict-Obrserve-Explain). The correspondence modulebased POE is one of the learning materials that applied the methods of learning as the stages work instruction as a handle for module-aided students. The result of module validation questionnaire filling by material experts and module experts can be seen in Table 1

\section{Table 1. Data on Module Validation Results by Material Experts}

EXPERT MATERIAL

\begin{tabular}{|c|c|c|c|c|c|}
\hline \multirow{3}{*}{ Validator } & \multirow[b]{2}{*}{ Variable } & \multirow[b]{2}{*}{$\sum \mathrm{x}$} & \multirow{4}{*}{$\begin{array}{r}\sum \mathrm{xi} \\
190\end{array}$} & \multirow{3}{*}{$\begin{array}{l}\% \\
88\end{array}$} & \multirow{9}{*}{\begin{tabular}{|c} 
Criteria \\
Very \\
Valid \\
Very \\
Valid \\
Very \\
Valid \\
Very \\
Valid
\end{tabular}} \\
\hline & & & & & \\
\hline & feasibility contents & 167 & & & \\
\hline \multirow{6}{*}{$\begin{array}{c}\text { Expert } \\
\text { Material } 1 \\
\text { Expert } \\
\text { Material } 2\end{array}$} & Feasibility & & & & \\
\hline & Presentation & 110 & 120 & 92 & \\
\hline & Feasibility Assessment & & & & \\
\hline & Language & 25 & 30 & 83 & \\
\hline & & & & & \\
\hline & Average & & & 89 & \\
\hline \multicolumn{6}{|c|}{ THE EXPERT MODULE } \\
\hline \multirow{10}{*}{$\begin{array}{l}\text { Validator } \\
\text { The expert } \\
\text { module } 1 \\
\text { The expert } \\
\text { module } 2\end{array}$} & $\begin{array}{l}\text { Variable } \\
\text { Feasibility }\end{array}$ & $\sum \mathrm{x}$ & $\sum x \mathrm{i}$ & $\%$ & $\begin{array}{l}\text { Criteria } \\
\text { Very }\end{array}$ \\
\hline & Presentation & 57 & 60 & 95 & Valid \\
\hline & Feasibility of Language & 30 & 30 & 100 & $\begin{array}{l}\text { very } \\
\text { Valid }\end{array}$ \\
\hline & & & & & Very \\
\hline & Feasibility Of graph & 219 & 240 & 91 & Valid \\
\hline & Average & & & 93 & $\begin{array}{l}\text { Very } \\
\text { Valid }\end{array}$ \\
\hline & Average Percentage & & & & Very \\
\hline & Amount & & & $91 \%$ & Valid \\
\hline & Expert material and & & & & \\
\hline & Expert Module & & & & \\
\hline
\end{tabular}

Source: Validation Results of quantitative Data Expert material and Expert module, 2017

Based on table 1 above, it can be concluded that the correspondence module based POE (Predict-Observe-Explain) that has been developed by researchers stated very valid, so worthy to be used in the learning activities. Fourth the validator gave excellent response. It can be seen from the average percentage of validations of $91 \%$. Based on the data of questionnaires in a small-scale trial conducted by 12 students, obtained a total validation percentage of $89 \%$. From these results it can be concluded that the Correspondence module-based POE (Predict-Observe-Explain) have criteria "very Valid/Usable". 
The Data analysis results of student learning is done by comparing the value of post-test between students who use the Correspondence module-based POE (Predict-Observe-Explain ) in experiments class with students who do not use the module on the control class. The Data analysis result of student writing skill obtained from post-test. If made with a diagram, it will appear like this:

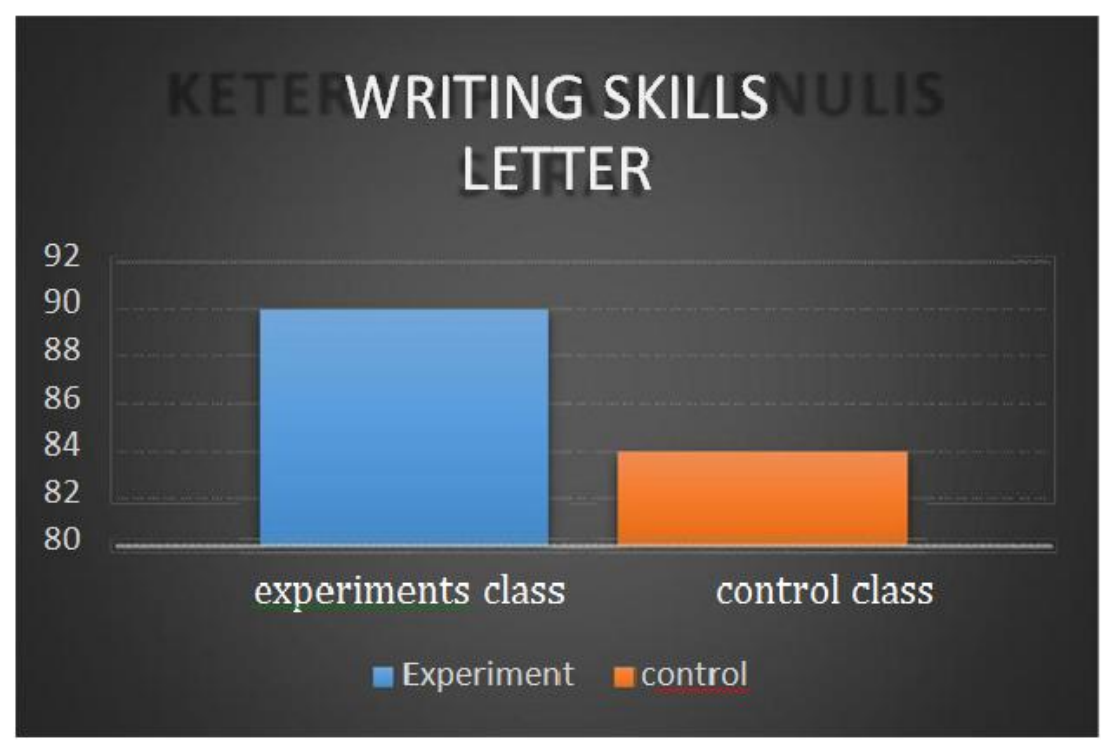

Figure 2. the results of average value Post-Test of Experimental and control class

Based on the data presented in Figure 2, it can be noted that the average value of the letter writing skills in students that using a Correspondence module-based POE (Predict-Observe-Explain) higher than the class that do not use the module in the learning activity. The difference between the mean of the experimental class and the control class is 6 , with the class completeness equal to $100 \%$. The increase occurred because in experiments class, the learning process is supported by the existence of a corresponding module-based POE (PredictObserve-Explain), while on the control class, not enforced Correspondence module-based POE (Predict-Observe-Explain) is only supported by powerpoint and explanations from the teacher. Thus it can be concluded that the correspondence module-based POE (Predict-Observe-Explain) effectively used in learning activities and can improve the skills of letter writing in students.

The first Output shows the average skills of letter writing experiment class is 89.92, while the average skills of writing a letter control class 84.31. This shows that the average letter writing skills learners experiments class of higher than average letter writing skills learners control class. The second Output shows the results of the independent sample t-test. In analyzing the results of the second output is done two times analysis, that analysis of the F count to test equality of variance analysis and $t$ count to test the difference in average. Analysis of Fcount shows 0.487 with significance of 0.488 ; because an Fcount $>$ 0.05; then both the class of homogeneous (equal), Until the test used is the equal variances assumed column because it has the same variation. Seen that the value of the test tcount 5,545 with significance of 0.000 ; because $0.000<$ 
0.05 , then there is a difference on average between the experimental and control group.

The results of these calculations show that the skills of letter writing students experiment group and control group, there is a significant difference so it can be stated that the Correspondence module-based POE (Predict-ObserveExplain) developed for effective use in the process of learning subjects of correspondence.

\section{Discussion}

Development of modules conducted by researchers that is produce in the form of printed learning materials, namely Correspondence Module-based POE (Predict-Obrserve-Explain) the subject matter of making procedures commercial letter. This Correspondence Module development using the learning model of POE (Predict-Obrserve-Explain). Correspondence Module-based POE is one of the learning materials that applied the methods of learning as the work module as a handle of students.

The model of learning POE is a learning model that is based on constructivist theory (Liew \& Treagust, 2004; Kibirig et al., 2014; Tlala, 2011; Ayvaci, 2013; White \& Gustone (in Karamustafaoglu, 2015); Widyaningrum, et al. 2013; Warsono \& Hariyanto, 2016).

The strategy is learning that POE is more meaningful than memorizing (Tlala, 2011; Karamustafaoglu, 2015; Kearney, 2004). The strategy of POE enables learners to hypothesize, test their hypothesis and explain observations (Kibirige et al., 2014). Can this model POE train students to solve problems (Nana, et al. 2014; Rifzal, et al. 2015; Widyaningrum, et al. 2013). In adintion, it can also increase students ' ability to think critically (Hilario, 2015; Tlala, 2011). The strategy presents a teaching strategy that POE is more effective (Ozdemir et al., 2011; Liew \& Treagust, 2004; Kala, 2013).

POE'S model can also be used to identify misconceptions on students or can reduce the misunderstanding of student (Ayvaci, 2013; Ozdemir et al, 2011; Kibirige, et al. 2014; Tlala, 2011; Nana, et al. 2014). This is due, three-step method of POE have of learning i.e., observing, predicting and explaining. As has been stated by Hilario (2015) that state "POE adalah strategi mengajar yang menuntut siswa melaksanakan tiga tugas. Pertama, siswa harus memprediksi beberapa peristiwa dan harus membenarkan prediksi mereka. Kemuinan mereka melakukan observasi terhadap apa yang mereka lihat, dan akhirnya menyelaraskan hasil prediksi dan observasi mereka". The participation of learners is marked with predict, observe and describe for the learning process (Kala et al., 2013; Tlala, 2011; Karamustafaoglu, 2015; Ayvaci, 2013).

The first phase i.e. predict (predicts), students have to predict what will happen before they are observed (Assessment Resource Banks, 2007). Teachers ask questions to attract students (Ayvaci, 2013). Then, a student asked to predict against events that will occur. The prediction phase has two parts. First, students choose a prediction, and second, select the reason in doing predictions Hilario, 2015; Tlala, 2011; Karamustafaoglu, 2015). With the prediction, will 
motivate students to find out about the correct answer (Tlala, 2011). The second stage i.e. observe (observe), students take note of the observations and doing demonstrations. The demonstration phase is an important component in at this phase, because in this phase, the students can see if one of their predictions are right or wrong (Hilario, 2015; Tlala, 2011). POE'S method allows to make connections between the experiment and the hypothesis (Ayvaci, 2013). At this phase the observe, teachers should be able to help students reconcile inconsistencies between predictions and observations of students (Hilario, 2015) because every student has views and its own answer.

The third phase i.e. explain (explain), students give an explanation about the suitability between the allegations and the truly happens (Suparno, 2007). Students make a conclusion that will assist students in clarifying the inscrepancy to what is foreseen and what happened (Hilario, 2015; Ayvaci, 2013). In this phase, the students are given time to give an explanation (Tlala, 2011). The implementation of this strategy is an essential tool in learning because it gives a sense of freedom between the students (Hilario, 2015). This is because this strategy involves students writing their predictions before doing the activity (Tlala, 2011). Method of POE provides knowledge for students to support predictions through the existing knowledge and experience from similar events they encounter in daily life (Ayvaci, 2013). Learning with POE models demanding students to active learning (student centered) and the teacher as a facilitator to support the learning process (Tlala, 2011; Nana, et al . 2014) Hilario, 2015 stated that "Bagian pentingnya yaitu menjelaskan perbedaan antara prediksi dan observasi. Dan juga, bagaimana siswa dapat menerapkan konsep di kehidupan sehari-hari"

POE'S model developed in the study due to be able to invite learners to build knowledge through experiential learners (Rahayu, et al. 2013). The activities of the scientific approach in the development of this module can be evidenced in the observe, where students perform observations and demonstrations as testing against a given problem. In the activities that students problems solve and being able to make something that was ordered by the teacher. Then presents the results of their work as proof of the work of students that will be communicated at this explain phase. Rifzal, et al. (2015:35) States that "Model POE ini dapat digunakan oleh guru sebagai cara untuk meningkatkan pemahaman siswa terhadap suatu konsep dan melatih keterampilan. Selain itu, model POE juga dapat meningkatkan komunikasi siswa dalam memberikan penjelasan terkait hubungan suatu kejadian yang diamati dengan teori". From the explanation above, it can be the conclusion that POE is an effective method and a method that can enable meaningful learning activities through performing and experiencing (Liew \& Treagust, 2004; Palmer, 1995; Ozdemir et al., 2011; Costu, 2008; Kearney, 2004). 
So it can be concluded that POE is an effective method and a method that can enable meaningful learning activities through performing and experiencing (Liew \& Treagust, 2004; Palmer, 1995; Ozdemir et al., 2011; Costu, 2008; Kearney, 2004).

The results of this research are supported by research conducted by Astawan, et al (2013) which indicates that an increase in student learning results after using the learning modules. The results of the study i.e. aspects of cognitive, affective and psychomotor. Research by Karangmustafaoglu (2015) stated that the experimental classes more successful than the control class. In adintion, research conducted by Nurhayati, et al (2013) also shows the existence of a class of classical completeness after using the module. In adintion, this research is also supported by research by Rahayu, et al. (2013:130) that stated that POE model can improve the results of the study because the students can use the knowledge that has been owned to explain a concept. The experience of student obtained after performing observe phase. These stages require to test against the predicted results obtained. Rahayu, et al. (2013:131) stated that the increase in psychomotor learning outcomes learner happens because learners become more skilled and visible delight in proving a theory. Learners are challenged to carry out more practical because they had to make early predictions in advance.

Difference research conducted is learning model of POE often used for research in the field of Science (Warsono \& Hariyanto, 2016), as research conducted by Liew \& Treagust, 1998; Widyaningrum, et al. 2013; Puriyandari, et al. 2014; Sari, 2016; Rifzal, et al. 2015). Learning model of POE is not only used in science, but also can be used in the field of social sciences as administration Science. Research in the social sciences such as the study by Tohiriyaningsih, et al. 2016 the title "Developing Modules of Merchaninsing Insplay Based on Predict Observe Explain (POE) in Echancing Students ' Achievement". The learning model of POE can be used in the field of social science and can improve writing skills of the letter because, the students learn gradually began by predicting in advance, until eventually the student have the skills in write the correct commercial. Moreover, at this phase of observe, students are trained to make the sentences in the letter until the concept of Commerce letter. So, using the learning model of POE, students may not necessarily be directly given material, but students are given freedom to propose hypotheses, and students have the skills to write a letter in Commerce.

Correspondence module-based POE (Predict-Observe-Explain) can improve the skills of letter writing because: (1) Model POE can be used by teachers as a way to improve the understanding of students of a concept and training skills (Rifzal, et al. 2015); (2) Costu, 2008 stated that " Langkah pertama dalam model POE ini adalah membuat prediksi atau dugaan. Pada tahap prediksi, guru memberikan fenomena kepada siswa, kemuinan siswa memberikan prediksi apa yang terjadi". The teacher asked the students to predict events that will occur or the answer to the problems. Students must be based on prediction theory and reasons. Students provide an explanation unconvincing that the results of their predictions are right. The application of 
Correspondence module-based POE is given a student questions about material that anglers will be discussed, and then the students give the hypothesis based on the question; (3) Costu, 2008 stated that " Langkah kedua yaitu melakukan observasi atau pengamatan. Pada tahap observasi, siswa mengamati fenomena dan guru membimbing siswa melakukan pengamatan agar sesuai dengan konsep ". At this phase, students not only observe, but students also do something accorinng to the command of the teacher. Implementation in the correspondence module-based POE is the students are given a matter of case studies such as the draft letter of Commerce, making sentences in Commerce, so that at this stage the students can practice in trading correct letter writing; (4) Suparno, 2007 stating " Langkah ketiga yaitu membuat penjelasan Eksplanasi adalah memberikan penjelasan tentang kesesuaian antara dugaan dan yang sungguh terjadi". Implementation in the correspondence module-based POE is students are asked to explain their work from stage predict and observe.

\section{SUMMARY \& SUGGESTIONS}

\section{Summary}

Based on stuines of the products developed by the researchers, there are some conclusions that are outlined as follows: 1) the results of development in this research in the form of correspondence Modules -based POE (Predict-ObserveExplain) for Sekolah Menengah Kejuruan (SMK) kelas X Administrasi Perkantoran, consisting of students and teacher module; 2) results of the validation of the module by module and material experts retrieved a percentage of an average of $91 \%$ and included in the category of very valid, so the modules developed by researcher worthy of use in the learning activities in the classroom. The results of the validation by $89 \%$ of students with very valid categories/can be used; 3) Module developed by researchers effectively used in the learning activities in the classroom, it is seen from the average skills of letter writing in experimentation and control class. The average value of experimental class of 90 and a control class of 84 by the different 6 . While the percentage completeness of the experimental class and control of $100 \%$.

\section{Suggestions}

Advice for teachers, in order to use the Correspondence module-based POE in learning activities in the classroom. While, Advice for students, in order to use correspondence module-based POE as one of learning resources.

\section{REFERENCES}

Assessment Resource Banks. 2007. Predict, Observe, Explain (POE).

Astawan, K. W., Santyasa, I. W., \& Tegeh, I. M. (2013). Pengembangan Modul Berbasis Model Pembelajaran Kooperatif Tipe Group Invertigation pada Mata Pelajaran Server Jaringan in SMK TI Bali Global Singaraja. E-Journal Program Pascasajana Universitas Pendidikan Ganesha, Vol. 3. 
Ayvaci, H. S. 2013. Investigating The Effectiveness of Predict- Observe-Explain Strategy on Teaching Photo Electricity Topic. Journal Of Baltic Science Education, 12 (5): 548:564.

Costu, B. 2008. Learning Science through the PDEODE Teaching Strategy: Helping Students Make Sense of Everyday Situasions. Eurasian Journal of Mathematics, Science \& Technology Education, 4(1) 3-9.

Daryanto. 2013. Strategi dan Tahapan Mengajar. Bandung : PT. Refika Aintama.

Hilario, J., S. 2015. The Use of Predict-Observe-Explain-Explore (POEE) as a New Teaching Strategy in General Chemistry-Laboratory. International Journal of Education and Research, 3 (2): 37-48.

Kala, N., Yaman, F. \& Ayas, A. 2013. The Effectiveness of Predict-Observe-Explain Technique in Probing Student's Understanding About Acid-Base Chemistry: A Case For The Concepts Of Ph, Poh, And Strength. International Journal of Science and Mathematics Education, 11: 555-574.

Karamustafaoglu, S. 2015. Understanding Electrochemistry Concepts using the Predict-Observe-Explain Strategy. Eurasia Journal of Mathematics, Science \& Technology Education, 11(5): 923-936.

Kearney, M. 2004). Classroom use of multimedia supported predict-observeexplain tasks in a social constructivist learning environment. Research in Science Education, 34 (4): 427-453.

Keeratichamroen, W. (2007). Using the Predict-Observe-Explain (POE) to Promote student's learning of tapioca bomb and chemical reactions.

Kibirige, I., Osodo, J. \& Tlala, K. M. (2014). The Effect of Predict-Observe-Explain Strategy on Learner's Misconceptions about Inssolved Salts. Meinterranean Journal of Social Sciences, 5(4): 300-310.

Liew, C.W \& Treagust, D. F. (2004). The Effectiveness Predict-Observed-Explain (POE) Technique in Inagnosis Student's Understanding of Science and Identifying Their Level of Achievement. Educational Resources Information Center (ERIC), TM 028 437:1-21.

Nana., Sajidan., Akhyar, M. \& Rochsantiningsih, D. (2014). The development of Predict, Observe, Explain, Elaborate, Write, and Evaluate (Poe2We) Learning Model in Physic Learning at Senior Secondary School. Journal of Education and Practice, 19 (1): 56:65.

Nurhayati, S., Parmin, \& Rizqi, A. M. (2013). Pengembangan Modul IPA Terpadu Berkarakter Tema Pemanasan Global untuk Siswa SMP/MTs. E-Jal 
Universitas Negeri Semarang. Unnes Science Education Journal, 2(1): 203:208.

Ozdemir, H., Bag, H. \& Bilen, K. (2011). Effect of Laboratory Activities Designed Based on Prediction, Observation, Explanation (Poe) Strategy on Pre Service Science Teacher's Understanding of Acid Base Subject. Western Anatolia Journal of Educational Science, 169-174.

Palmer, D. H. (1995). The "POE" in the primary school: An evaluation. Research in Science Education, 25(3) 323:332.

Puriyandari, D., Saputro, A. N. C. \& Masykuri, M. (2014). Penerapan Model Pembelajaran Prediction, Observation And Explanation (POE) Inlengkapi Lembar Kerja Siswa (LKS) Untuk Meningkatkan Sikap Ilmiah dan Prestasi Belajar Materi Kelarutan dan Hasil Kali Kelarutan Siswa Kelas XI IPA Semester Genap SMA Negeri 1 Ngemplak Tahun Pelajaran 2012/2013. Jurnal Pendidikan Kimia, 3 (1).

Rahayu, S., Widodo, A.T. \& Sudarmin. (2013). Pengembangan Perangkat Pembelajaran Model POE Berbantuan Media "I am a Scientist". Innovite Journal of Curriculum and Educational Tecnology, 2 (1): 128-133.

Rifzal, I. L., Akmam, \& Hurhayati. (2015) Pengaruh Penggunaan LKS Berbasis POE Dalam Pembelajaran IPA Terhadap Kompetensi Siswa Kelas VII SMPN 5 Padang. Pillar Of Physic Education, 6:33-40.

Sari, A. T. W. \& Alarifin, D. H. (2016). Pengembangan Modul Berbasis POE (Predict, Observe, Explain) Materi Usaha Dan Energi Intinjau Dari Kemampuan Kognitif. Jurnal Pendidikan Fisika, 4 (2): 123-136.

Setyosari, P. (2013). Metode Penelitian Pendidikan \& Pengembangan. Jakarta: Kencana.

Suparno, P. (2007). Metodologi Pembelajaran Fisika. Yogyakarta: Universitas Sanata Dharma.

Tlala, K. M. (2011). The Effect Of Predict-Observe-Explain Strategy On Learner's Misconceptions About Inssolved Salts. Insertasi inpublikasikan. Australia: University of Limpopo.

Tohiriyaningsih, E. Y., Pratikto, H. \& Chuyirah, M. (2016). Developing Module of Merchaninse Insplay Based on Predict Observe Explain (POE) in Enhancing Students' Achievement. IOSR Journal of Research and Method in Education (IOSR-JRME), 10 (10): 1-9.

Undang-Undang RI No. 20 Tahun 2003 tentang Sistem Pendidikan Nasional. UU Nomer 20 Tahun 2003-Inrjen Sumber Daya Iptek Inkti. 
Warsono \& Hariyanto. (2016). Pembelajaran Aktif. Bandung: PT Remaja Rosdakarya.

Widyaningrum, R., Sarwanto. \& Karyanto, P. (2013). Pengembangan Modul Berorientasi POE (Predict, Observe, Explain) Berwawasan Lingkungan Pada Materi Pencemaran Untuk Meningkatkan Hasil Belajar Siswa. Jurnal Bioedukasi, 6 (1): 100. 